\title{
Journal Impact Factor Returned to Acta Cytologica in 2020
}

We are delighted to announce that the journal impact factor (JIF) of Acta Cytologica was finally released in June 2020 , after 6 years of interruption. The new JIF of 2019 is 1.226 .

Those of you who would like a reminder of the technical details of how the JIF is calculated, the reasons given for the removal of Acta Cytologica's JIF in 2014, and our subsequent appeals in 2017, 2018, and 2019, we would like to refer to the following Editorial and Publisher's Notes [1-3], as it is not feasible to reiterate the whole intriguing story in this short Editorial.

The main purpose of this Editorial is to extend deep thanks and gratitude to all of you who have supported the journal over the past 6 years, i.e., the period when Acta continued without a JIF. Particular thanks go to our Editorial Board, Guest Editors, and contributors to special issues, peer reviewers, and naturally to our committed authors who never lost their faith in Acta Cytologica. Many of you who have not been able to contribute in those ways still took the time to sign an online petition for the return of the JIF in 2017, in which an incredible number of over 1,000 signatures were collected. Your help in this project was invaluable and we thank you for your support!

\section{So, What Does This Mean for the Future?}

First, we expect to see an increasing number of submissions - particularly from authors working in countries or institutions that place great weight on the JIF. We warmly welcome these submissions. In particular, we would like to receive high-quality original papers, metaanalyses, comprehensive reviews, technical innovations, and particularly interesting case reports (with a comprehensive literature review). In this respect, the priorities in the publication policy of Acta Cytologica have not significantly changed [4].

Second, we will introduce sections on events and news from the International Academy of Cytology (IAC) and affiliated national societies. During this time of COVID-19, it is more important than ever to have a central reference point for our community. Being the official journal of the IAC, Acta Cytologica is a truly unique and global cytological journal reaching different regions of the world - even those that in the past had less access to the medical literature. For the last $60+$ years, a printed copy of Acta Cytologica has been on the coffee table of pathology laboratories across the world - this will not change!

Kari Syrjänen, Editor-in-Chief

Fernando Schmitt, General Secretary IAC

\section{References}

karger@karger.com

www.karger.com/acy

Karger
1 Syrjänen K, Vielh P, Schmitt F, Nold T. Editorial. Acta Cytol. 2015;59(1):1.

2 Publisher's Note. Publisher's Note. Acta Cytol. 2017;61(4-5):257-8.
3 Publisher's Note. Publisher's Note. Acta Cytol. 2018;62(5-6):317-317.

4 Syrjänen K. Keynotes from the new editor-inchief. Acta Cytol. 2013;57(6):543-4. 